Article

Niklas Sandell*

\title{
The Rhetorical Handling and Construction of Uncertainty in Tax Litigation Concerning Valuation of Financial Instruments
}

https://doi.org/10.2478/ntaxj-2021-0001

Received Aug 04, 2020; accepted Apr 12, 2021

\begin{abstract}
A tax litigation concerning the value of nontraded financial instruments is impregnated by uncertainty. The aim of this paper is to study how uncertainty inherent in financial valuation models is discursively and rhetorically handled and constructed by the litigating parties as well as the court. A discourse analysis guided by the notion of hedging is conducted on The Swedish Tax Agency v. $P w C(2013,2014)$. The analysis demonstrates a sparse use of hedging. Rather, certainty characterizes tax litigation. However, the analysis shows that the litigating parties as well as the court participates in the construction of claims as facts, distancing themselves from their own claims and decisions.
\end{abstract}

Keywords: Tax litigation, Financial instruments, Rhetoric, Uncertainty, Discourse analysis, Hedging.

\section{Introduction}

In this paper the case The Swedish Tax Agency v. PwC (2013, $2014)^{1}$ is examined. The question for the court to decide on was whether a tax benefit, which would render payroll tax, had arisen when employees acquired shares in the company (i.e. PwC). The Tax Agency argued that the employees becoming partners of the audit firm (PwC) had acquired the shares at a price lower than the market value, hence the difference should be regarded as a tax benefit on which the company should report payroll tax. Establish-

\footnotetext{
^Corresponding Author: Niklas Sandell: Senior Lecturer of Business Administration, Knut Wicksell Centre for Financial Studies, School of Economics and Management, Lund University, Lund, Sweden. E-mail: niklas.sandell@fek.lu.se

1 In this paper treated as one case The Swedish Tax Agency v. PwC tried first by the Administrative Court in Stockholm 2013 [Förvaltningsrätten i Stockholm, mål nr 7382-7385-13] and then by the Administrative Court of Appeal in Stockholm 2014 [Kammarrätten i Stockholm, mål nr 701-702-14]. (Swed.)
}

ing a market value for a non-traded company is normally done by discounting the projected future cash-flow of the company to a net present value using a discount rate corresponding to a market-based yield. Neither the future cashflow of the firm nor the market-based yield of this particular financial instrument can be directly observed in practice. In that sense an estimated market value of necessity rests on flawed financial models and unobservable data (Hilling, Sandell, and Wilhelmsson 2019). These preconditions, in combination with the judges, including the professionals, being laymen when it comes to financial economics, places great demands on the litigating parties arguing the case as well as on the ability of the court to write a convincing decision.

Within any legal system the court of law needs to make decisions under uncertainty, regarding the strength of the evidence presented, the scientific support for a claim, and the credibility of the stories told (Bazelon 1981; Enough and Mussweiler 2001; Gold 2006; Mortensen and Mortensen 2017; Tai 2008). Hence, decisions leaning on probabilities (Cheng and Cheng 2014; Hamer 1994; Robertson and Vignaux 1993) and beliefs are a necessity. Knowledge of the handling of uncertainty in court proceedings is therefore important both in order to understand how faith in the legal system is maintained, and in order to evaluate a court decision and the rule of law. In the words of Hinkle et al. (2012, 408): "any insight into the ways in which judges choose the form of their language offers insight into the functioning of our judicial system."

The degree of uncertainty varies from case to case, but can also be discussed from the viewpoint of the type of case. In one type of case the decision, like the reality the decision concerns, is binary, either you are guilty or you are not. The decision then concerns two possible alternatives, of which one is correct. In that sense the decision, if correct, can reflect reality. When the decision concerns a continuum however, as is the case with the valuation of financial instruments in tax litigation, the degree of uncertainty increases. The continuum is limited, though, according to Swedish procedural law, by the claims of the lit- 
igating parties (Almgren and Leidhammar 2016), ${ }^{2}$ which frames the possible outcomes and hence the decision of the court. The court cannot rule on a higher value than claimed by the Tax Agency. Therefore, the Tax Agency sets the upper limit and the taxpayer, the lower. Adding to the uncertainty invoked by the continuum, the uncertainty further increases when the decision by necessity to a large extent must be based on factors that are not observable, such as future cash-flows and a discount rate, as is the case when performing a valuation of non-traded financial instruments (Hilling, Sandell, and Wilhelmsson 2019). This paper deals with the handling and construction of uncertainty in tax litigation when establishing a value for a nontraded financial instrument. This situation captures both the above-mentioned aspects of uncertainty: the indefinite number of possible values, and the dependence on nonobservable data.

There is a vast amount of research on the rhetoric of court decisions, concerning both the creation of reality through the narrative (Ekström 2003; Higdon 2009; Sherwin 1993) and the rhetorical handling and construction of uncertainty (Cheng and Cheng 2014; Corley and Wedeking 2014; Vass 2004, 2017). The term rhetorical handling is here referring to the attempt to make a claim believable, trustworthy, or convincing when an argument or a decision is presented. The importance of rhetoric when presenting the grounds for a decision, legitimizing it, cannot be overemphasized. The decision is based on a judgment of everything that is displayed to and experienced by the court, such as factual evidence and appearance by the litigating parties. In the court's decision-making process, as judges apply meaning-creating schemata or interpretative frameworks, formed by preexisting knowledge (Berger 2008; Higdon 2009; Newberg 2002; Sherwin 1993; Vass 2004), the rhetorical challenge to convince the courts, and for the courts to explain their ruling, increases as the uncertainties of a case increase.

The aim of this paper is to study how the uncertainty inherent in financial valuation models is discursively and rhetorically handled and constructed by the litigating parties as well as by the court. As handled refers to a conscious act, the term constructed refers to that writing a text is part of the construction of uncertainty, no mat-

2 According to the Administrative Court Procedure Act (1971:291) [Förvaltningsprocesslag], Section 29, the decision of the court must not go beyond what is claimed in the case. However, if there are special reasons, the court may, even without a request, decide in favor of the individual, when this can be done without harm to opposing individual interest. (Swed.) ter if it is the writer's intention or not. The analysis of the degree of certainty by which a claim is expressed is guided by the notion of hedging, broadly defined as "a discoursal resource for expressing uncertainty, skepticism, and open-mindedness about one's propositions" (Hyland 1996b, 434).

There is some research, although not that extensive, concerning epistemic stance taking and hedging in court decisions (Cheng and Cheng 2014; Corley and Wedeking 2014; Hinkle et al. 2012; Vass 2017; Toska 2012). This paper contributes to the previous research mainly in two ways. First, the study focuses not only on the arguments of the court, which is most often the case, but also on the stories presented by the litigating parties, which are the stories the court use as a basis to form its own story. In that sense this study acknowledges that the formulation of a final story by the court is formed from the dialogue between the litigating parties. Secondly, as a qualitative study the paper emphasizes the importance of interpreting uncertainty and the rhetorical handling and construction of it in its context, which is necessary to really understand the signification of the language use in making a convincing argument. Using the notion of hedging to dissect how claims are discursively constructed, the paper contributes to the more general understanding of the handling of uncertainty in court proceedings.

The paper is structured as follows. In the next section important aspects of the Swedish legal system and procedural law are briefly introduced. This is followed by a presentation of the case examined, and an extended discussion of how company valuation creates a legal rhetorical dilemma in tax litigation. The dilemma in short being the difficulty for the Tax Agency to argue for a value that is based on future events and for the courts to apply a law that assumes that these future events can be established. Thereafter follows a presentation of the research design, presenting the method used and material studied. The theoretical positioning of the paper, within the field of epistemic stance taking and hedging, is introduced. The findings concerning the handling and construction of uncertainty are presented, illustrated by excerpts from the documents studied. The paper ends with a discussion of the findings and conclusions.

\section{Swedish procedural law}

In order to make this study understandable, regarding both its research design and the interpretative discussion 
of the case, some aspects of the procedural law in Sweden, regarding tax litigation, will be briefly introduced.

The proceedings start with an administrative decision by the Tax Agency, normally increasing the tax burden on the taxpayer compared to the taxes declared. If the taxpayer does not agree with the decision, the first step is to demand the decision to be reconsidered by the Tax Agency. The Tax Agency then reviews the matter leading to a review decision. This decision can be appealed to the Administrative Court [Förvaltningsrätten], where the review decision, together with a mandatory review decision, ${ }^{3}$ sets the position of the Tax Agency (Almgren and Leidhammar 2016). The decision by the Administrative Court can be appealed to the Administrative Court of Appeal [Kammarrätten] and in a second step to the Supreme Administrative Court [Högsta förvaltningsdomstolen]. The Administrative Court-the first instance-has a quorum with one legally qualified judge and three lay judges and the Administrative Court of Appeal has a quorum with three legally qualified judges. ${ }^{4}$ The main rule is that the procedure is in writing. There are however no statutory regulations on how the written procedure should be conducted (Lavin 2020). The court can also decide to hold oral hearings if it benefits the examination. In the case studied one oral hearing with expert witnesses was held as a complement to the written procedure (a transcript of this hearing is included in the documents studied, see Table 1).

The official principle guides the procedures in the court. This principle implies that the court is mainly responsible for conducting the investigation and for ensuring that all required documents are handed in. The court can, on its own initiative, ask for opinions that require certain expertise, such as from authorities. Also, the litigating parties may submit expert opinions from law professors and other experts. In the case studied, PwC submitted expert opinions from two finance professors. The court has by no means an unlimited responsibility for the investigation (Almgren and Leidhammar 2016). Rather, the primary task of the court is to guide the litigating parties to submit a reliable basis for the decision. If the court assumed too much responsibility for the investigation, its objectivity and impartiality could be jeopardized, especially if such investigative measures were to the disadvantage of the taxpayer. The Tax Agency is responsible for investigat-

3 In accordance with the Tax Procedures Act (2011:1244) [Skatteförfarandelagen], Chapter 67, Section 20, an appeal shall be subject to a mandatory review by the Tax Agency. (Swed.)

4 The Supreme Administrative Court is not discussed here since the ruling of the Administrative Court of Appeal was not appealed. ing the tax case, and as a main principle, the Tax Agency has the burden of proof regarding income and the taxpayer regarding deductions. In the case studied the Tax Agency must prove, i.e. convince the court, that the shares in $\mathrm{PwC}$ are worth an amount that substantially exceeds the acquisition price, implying a higher income. The taxpayer can of course make the argument that the price charged for the shares is market-based, but it would be enough to convince the court that the Tax Agency has not been able to show the opposite.

In ordinary taxation the evidentiary requirement is "probable." Although there seems to be no consensus about the precise meaning of probable, it is normally estimated to correspond to a 75 percent probability (Diesen 2003; Lindkvist 2016). Hence, in a case where the Tax Agency considers that a taxpayer has reported low income, it is the responsibility of the agency to prove, with a requirement of 75 percent probability (a concrete expression of a particularly abstract relationship), that the taxpayer has had additional income. In cases, such as The Swedish Tax Agency v. PwC (2013, 2014), where the size of the income is determined by a market valuation of the received compensation, the Tax Agency must show that the taxpayer has performed a questionable market valuation. In addition, to prove its case, the Tax Agency must also present a market valuation that is substantially more in accordance with actual conditions than the estimated market value the taxpayer has used as a basis for the tax declaration.

\section{The case and the rhetorical dilemma}

$\mathrm{PwC}$ is a partner-owned audit firm. In general, a partnerowned company is defined as a company where the majority of the votes are controlled by a limited number of individuals and where these individuals work in the company (Hilling, Sandell, and Vilhelmsson 2017). In a partner-owned company, the profit for the year is distributed among the partners. Only those appointed as partners may acquire shares in the company. The primary purpose of the shares is to function as a distribution mechanism, and shareholding is normally also associated with restrictions and conditions regarding acquisitions, ownership, and divestment. The return on a share is not a result of a capital investment. Rather, the partners choose to tax the operating surplus as income from capital because it is more favorable. In Sweden income from work is taxed separately from income from capital. Because the tax rates in 
the two types of income differ significantly, there are special rules (called the 3:12 rules after the Chapter and Section of the tax code in which they were first introduced) to prevent high-taxed labor income from being taxed as income from capital at a lower tax rate (Edin and Lodin 2008). According to the letter of the law ${ }^{5}$, however, the partner-owned company can choose, even if there is a relatively large number of shareholders, whether the surplus from the business should be transferred to the individual as income from the employment, in the form of wages, or as income from capital in the form of dividends, implying the possibility of a significant tax arbitrage.

The core question of the case is whether employees acquired shares in the company at a favorable price. If so, there exists a taxable benefit that should be reported as income during the year of the acquisition. $\mathrm{PwC}$, the employer, would then have to declare payroll tax on these benefits. Hence, what is on trial in the case is whether additional payroll tax should be imposed on $\mathrm{PwC}$ as a result of employees' preferential acquisition of shares. When calculating such payroll tax, the value of the benefit shall be determined in accordance with the Income Tax Act's rules on market value. ${ }^{6}$

Valuing a share in a partner-owned company is a difficult task. The approach taken by the Tax Agency is that it is possible to establish the future cash-flows to and from the entity and a market-based discount factor-i.e. the return the average actor on the market would require to invest in the company-employed to discount the future cashflows to a net present value. As can be understood from the description of the valuation model-even if it is theoretically correct-any company valuation is speculative by nature. When valuing a partner-owned entity it becomes even more so. The level of difficulty increases if one also needs to consider aspects such as a non-liquid market (see for example Longstaff 2018), emption rules, an ownership that is contingent on labor performance and where subordinated loans are required from the shareholder to the company.

The details of the case are that $45 \mathrm{PwC}$ employees, in the year 2010, acquired a total of 1,380 shares in the company, at SEK 10 per share. The Tax Agency estimated the market value of one share to be SEK 35,000-i.e. 3,500 times the acquisition price, in itself telling us something about the extreme number of possible outcomes of a

5 Inkomstskattelag (1999:1229) [IL] [Income Tax Act], Chapter 57 Section 3 (Swed.).

6 Inkomstskattelag (1999:1229) [IL] [The Income Tax Act], Chapter 61 Section 2 (Swed.). valuation-and therefore decided to raise the basis for payroll tax (the Swedish Tax Agency's review decision on December 20, 2012). PwC appealed the decision of the Tax Agency to the Administrative Court, which decided in favor of PwC. The Tax Agency in turn appealed the decision by the Administrative Court to the Administrative Court of Appeal, which also ruled in favor of PwC.

The courts' interpretations of the case requisites have previously been discussed by Hilling, Sandell, and Vilhelmsson (2017) and the quality of the Tax Agency's litigation by Hilling, Sandell, and Vilhelmsson (2018). In this paper, however, neither the legal issue nor the process of litigation is in focus, but the rhetorical handling and construction of the inherent uncertainties in a company valuation, and the importance of rhetoric in making a convincing argument for one's position.

The rhetorical dilemma is not restricted to the application of a specific rule. Rather it must be viewed in the context of a wider understanding of legislation. The law rests on the assumption that it is possible to objectively determine the amount of tax one should pay. Benefits are taxed neutrally in relation to cash payments. ${ }^{7}$ Assets other than cash (such as shares in a company) then have to be valued at their market value. The legislator thus assumes that all forms of compensation are possible to value objectively for income tax. The reason for this assumptionknowing that it is not actually true-is that otherwise it would be possible to perform non-taxed value transfers by structuring a transaction in such a way that it becomes non-valuable. Therefore, the legislator had to either accept that it is not possible to objectively determine a market value on some assets, but then allow the transfer of values through structured transactions that would not be taxed, or assume that it is possible to objectively determine a market value, leaving it to the Tax Agency and the courts to handle the dilemma. The legislator chose the latter. Evidently, it is no simple task to objectively prove that a particular market valuation is substantially better than another. The Tax Agency's evidentiary requirements in cases where the facts relate to market valuation of assets can therefore be extremely challenging.

Also the taxpayer, PwC, must tell a credible story, not necessarily proving that the price paid is absolutely correct, but that the Tax Agency has not shown that the value is higher. In the taxpayer story, however, for two reasons, it is not possible to make the argument that it is impossible to assign a market value to the shares. First,

7 Inkomstskattelag (1999:1229) [IL] [The Income Tax Act], Chapter 61 Section 2 (Swed.). 
the legislator has decided that it is possible and therefore such an argument-no matter whether it is accurate or not-can hardly lead to success. Secondly-which makes this case particularly interesting-PwC works professionally performing valuation of non-traded companies, also for use in legal contexts, such as tax litigation.

\section{Research design and material}

The study is based on detailed analyses of two court rulings (one case) and the written argumentative documents presented to the court by the litigating parties. Hence, the empirical material consists of the decisions in the Administrative Court and the Administrative Court of Appeal, minutes taken by the Administrative Court regarding one oral hearing, as well as all submitted argumentative documents presented by the Tax Agency and PwC, i.e. a total of thirteen documents (Table 1).

The court decision documents, which are an important part of the empirical material, contain the claim, the pleas, the opposing party's position, evidence and an account made by the court of the facts as presented by the litigating parties in support of their position. It also includes an account of the content of applicable legislation, and the court's assessment. The assessment contains the reasons the court has for its decision (Almgren and Leidhammar 2016). It is the reasons that are studied here, since it is under this heading the court argues for its conclusion, i.e. making their knowledge claim. Knowledge claim refers to a statement that will be subjected to evaluation, as opposed to a statement that is accepted as fact (Crompton 1997; Hyland 1994, 1996b). In Swedish procedural law it is up to the judges in the individual case to decide how to present the reasons. Nonetheless, the court is supposed to explain why the case has the current outcome, in a clear and logical manner (Lavin 2020).

All documents studied are presented in Table 1 in chronological order, starting with the Tax Agency's review decision of December 20, 2012.

The documents presented in Table 1 have been studied through close reading of the texts and analyzed within the discourse of tax litigation and company valuation, considering the language use and constraints in a specific legal discourse handling financial economics. The language within any discourse produces and reproduces ideas and facts. In doing so, the present discourse brings order to society, because it makes it comprehensible (Svensson 2019), enabling us to think and act. When analyzing texts within a particular discourse one has to understand that, within the discourse, facts and truths are constructed and molded. Once accepted as a fact or a truth by the discourse community, the common understanding of the world, as a shared knowledge, tends to be hard to challenge.

A close reading enables the researcher to take into account a preunderstanding of the discourse. It will of course be the researchers' interpretation of what the texts convey, not of the writer's intention behind the text or how the texts are interpreted by a larger group of readers (the discourse community as a whole). However, the text itself is a communicative vessel that communicates something independently of what the writer intended to communicate. It is an intermediary between writer and reader, which allows a study of the properties of the text through the researcher's close reading (Myers 1989) and discursive interpretation.

The search for textual items-words and phrases-in this study that deals with the handling of uncertainty was guided by the notion of hedging, and the linguistic structure it rests on, in order to organize the process of identifying how the uncertainty of claims made was constructed. Such analysis, as suggested by Hyland (1996b), benefits from emphasizing the institutional, professional, and linguistic contexts. Hence, analyzing the rhetorical handling and construction of uncertainty in knowledge claims requires contextual understanding, especially regarding the use of company valuation as a basis for taxation, i.e. how something subjective is incorporated into a claim or a decision that at least must appear as objective.

Even though a discourse such as the one analyzed in this paper might seem hard to grasp, impossible to clearly define, and having floating boundaries, it does not make fewer requirements of a structured analysis, but rather enhances the need for it. Svensson (2019) describes discourse analysis research as creative interpretative work, which follows from a systematic research process. Whereas the study of the context, i.e. the need to understand the wider background to the texts studied-in this study the letter of the law, procedural justice traditions, company valuation models, financial theory and practice, the writers and their purposes-can shed light upon the text, the texts can at the same time illuminate and enhance the understanding of the context (Prasad 2005). In other words, the texts tell us something about the uncertainty of the context, and an interpretation of the uncertainty of the context helps us identify items of texts that deals with uncertainty.

The first step of the close reading was to search all document for items of texts that rhetorically handle or construct uncertainty. This search has been an iterative process. Every time a new expression was identified all documents were searched for such expressions. In the second 
Table 1: Documents studied in chronological order.

\begin{tabular}{|c|c|c|}
\hline Document & Date & Origin \\
\hline Review decision & December 20, 2012 & Tax Agency \\
\hline $\begin{array}{l}\text { Reply to the review decision of December } 20 \text {, } \\
2012\end{array}$ & January 31, 2013 & $\mathrm{PwC}$ \\
\hline $\begin{array}{l}\text { Appeal to the Administrative Court of the deci- } \\
\text { sion of the Tax Agency }\end{array}$ & March 25, 2013 & PwC \\
\hline Mandatory review decision & March 26, 2013 & Tax Agency \\
\hline $\begin{array}{l}\text { Court minutes from oral hearing of representa- } \\
\text { tives of the Tax Agency and by PwC called expert } \\
\text { witnesses }\end{array}$ & October 22, 2013 & Administrative Court in Stockholm \\
\hline Supplementary comments & October 23, 2013 & Tax Agency \\
\hline $\begin{array}{l}\text { Comment on the supplementary comment by } \\
\text { the Tax Agency as of October } 23,2013\end{array}$ & October 30, 2013 & $\mathrm{PwC}$ \\
\hline Court ruling & December 3, 2013 & Administrative Court in Stockholm \\
\hline Appeal to the Administrative Court of Appeal & January 31, 2014 & Tax Agency \\
\hline Plea to the Administrative Court of Appeal & February 28, 2014 & $\mathrm{PwC}$ \\
\hline Final remark & April 14, 2014 & Tax Agency \\
\hline Final remark (including a commentary by expert) & May 28, 2014 & PwC \\
\hline Court ruling & December 22, 2014 & Administrative Court of Appeal in Stockholm \\
\hline
\end{tabular}

step, the identified expressions were clustered into overall categories, in order to make it possible to analyze different forms of rhetorical handling of uncertainty. Three main categories were identified: (1) clarification of the knowledge claim, (2) references to the litigating parties (oneself or the counterparty) and (3) references to the knowledgeable. This thematic categorization has been guided by empiricism and context (Charmaz 2006) and is a result of repeated comparisons, classifications, and groupings.

In order to reduce the risk of translation losses (Evans 2004) all analysis has been performed on the original texts in Swedish, since the documents were originally written in Swedish. All excerpts used in this paper for illustrative purposes have then been translated by the author into English.

\section{The handling and construction of uncertain knowledge claims}

In order to study the rhetorical handling and construction of uncertainty, the linguistic idea of hedging has been applied, to identify items of texts used to construct the relationship between claim and fact, between the uncertain and the certain. Epistemic modality, the theoretical point of departure, refers to linguistic expressions of certainty and uncertainty, ranging from total uncertainty to abso- lute certainty (Mortensen and Mortensen 2017; Vold 2006). In the words of Lyons $(1977,797)$ an epistemically modal or modalized sentence is any "utterance in which the speaker explicitly qualifies his commitment to the truth of the proposition expressed by the sentence he utters."

Although, epistemic modality is the theoretical point of departure, this linguistic idea of how single words might place uncertainty on a scale (although not numerically), ranging from uncertain to certain, where the degrees of certainty can be expressed by the modal adverbs "certainly," "probably," and "possibly" (Lyons 1977, 800) or by more or less strong versions of those, the concept of hedging has been expanded to cover a wider set of expressions. The aim of this paper, to study how uncertainty, that are an inescapable part of a company valuation being presented to and argued before a court and judged upon by a court, is rhetorically handled and constructed, also goes beyond what would normally be regarded as hedging. It is not the hedges per se that are scrutinized. The aim is neither to develop the definition of a hedge, nor to develop a typology of hedges.

Whereas hedges tend to soften the facticity, rhetorically functioning as acknowledging that it is not absolutely certain, opening up for there being other possible interpretations, other rhetorical constructs close the gap, albeit still working on the scale from uncertain to certain. Even though we start from epistemic modality and the notion of hedging, the paper goes further, trying to under- 
stand how uncertainty is rhetorically handled and constructed within tax litigation.

In the literature, there is a broad consensus regarding the general definition of a hedge. An opinion is either already confirmed within the prevailing discourse community, in which case the statement is regarded as a fact, or will be subjected to evaluation by the discourse community, the statement being considered as a knowledge claim (Crompton 1997; Hyland 1994, 1996b; Lewin 2005). A knowledge claim is characterized by uncertainty and it is fair to say that the use of hedges signals uncertainty and distance to knowledge claims. "In natural language [sometimes referred to as everyday language in order to distinguish the language from other symbolic languages such as numerical language (Sandell and Svensson 2016, 2017), my remark], truth is a matter of degree, not an absolute," says Lakoff $(1973,491)$. When a writer or a speaker makes use of hedges, he or she signals the uncertainty or the preliminary nature of the utterance (Hyland 1996b). This does not only indicate uncertainty, but might also make the knowledge claim more accurate, believable, or convincing to a certain audience.

By means of hedging, a writer can articulate his or her degree of commitment to the utterance, hence qualify the truth value of a certain proposition and thereby specify the degree of truth in a certain claim (Hyland 1996a). When hedges are used to give an accurate description of the degree of uncertainty they can be labeled "real hedges." A "strategic hedge," on the other hand, is a part of the conventions of a discourse, employed to express "tentativeness, cautiousness, politeness and a humble attitude" (Vold 2006, 81). Mitigating a claim by marking it as provisional, pending acceptance by the readers, hedging can be regarded as a politeness strategy (Myers 1989). Hedging in that sense reflects a relation between the writer and the readers-the discourse community-not necessarily the degree of certainty of the claim. As such a hedge, says Crompton (1997), may be used to display not only the writer's degree of confidence in the proposition, but also how much confidence he or she feels is appropriate to display.

Therefore, a hedge might increase the accuracy of a knowledge claim, it might be used to convince or influence the reader (Hyland 1996a; Vold 2006), but can also be used in order to protect the one uttering the claim, or to uphold a dialogue and the status of those participating in the dialogue. The written text is part of an interaction between a writer and a reader (Hyland 1994; Myers 1989), the interaction consisting of the writer considering the background knowledge, interpretation processes and reactions, whereas the readers try to predict the writers' line of thought, position, and intentions. This is no less important in legal discourse than in, for instance, academic discourse, since the reader, in very much the same manner, is supposed to scrutinize the propositions put forward by the writer.

Even though there seems to be general consensus about the overall notion of hedges, there is no broad consensus on how to operationalize the notion of hedging for items of text (Crompton 1997; Resche 2015; Vold 2006). Hyland (1996b), for instance, applies a rather broad definition of what may constitute a hedge, including conditional clauses, non-personal expressions, explicit references to the speaker, and passive forms. Crompton (1997), on the other hand, narrows the definition to epistemic modality markers, a language unit used to explicitly limit the certainty of the truthfulness of a knowledge claim.

Hedges are used, argues Hyland (1996a, 1996b) taking a broader perspective on the concept, not only to define the knowledge claim, but also to adjust the strength of the knowledge claim based on what is considered appropriate in a particular context or for certain recipients (Hyland 1996a, 1996b). When writers use hedges, they also display adherence to communicative rules and a "wider system of politeness" (Hyland 1996b, 434). In some discoursefor instance the academic discourse-too bold and certain knowledge claims may jeopardize the legitimacy of the writer and the hedge is a way of mitigating the personal accountability for a certain claim, and provide the opportunity to adjust the degree of certainty according to the expected reader response (Hyland 1994, 1996a). This paper adheres to the notion that what constitutes a hedge, as all rhetorical handling and construction of uncertainty, is context-dependent (Clemen 1997; Hyland 1996b; Mortensen and Mortensen 2017; Resche 2015).

Research on hedging in written text has mainly been concerned with academic writing (Crompton 1997; Hyland 1994, 1996a, 1996b; Vold 2006). Most ideas concerning hedging have been developed here and have then been transferred to other discursive practices, such as politics (Jalilifar and Alavi 2012; Taweel et al. 2011) and financial communication (Hyland 1998; Klimczak and Dynel 2018; Klimczak, Dynel, and Pikos 2016; McLaren-Hankin 2008; Wang, Li, and Cao 2012). There are also some studies of the rhetorical handling and construction of knowledge claims and the use of hedges in the practice of law (Chen and Cheng 2014; Szczyrbak 2013; Vass 2004, 2017).

Cheng and Cheng $(2014,23)$, studying the use of epistemic modality in different jurisdictions, state that modality is of particular importance in a legal setting, since it deals with reliability, admissibility of evidence, and burden of proof. Epistemic modality is used as an "evalua- 
tive mechanism of proof in the court judgments.” In both the jurisdictions studied here, it is accepted that "absolute certainty is unattainable." On the other hand, Corley and Wedeking (2014), studying how the language used by the US Supreme Court influences lower courts, found that as the level of certainty increases, the lower courts are more likely to treat the decision positively. The "Supreme Court can increase compliance by using more certain authoritative language in its opinions" (Corley and Wedeking 2014, 51). In the same vein, Szczyrbak (2013), studying how epistemic verbs are used by trial participants, concluded that they avoid verbs marking doubt or pointing to their lack of knowledge, also indicating the need to appear certain. On the other hand, hedging has, according to Vass (2017, 17), "a particularly important role in nuancing language in such language-dependent disciplines as law.” In a study of epistemic lexical verbs in different legal genres, Vass (2017) concluded that the pattern of use in each genre can be linked to different communicative purposes.

However, the studies cited are mainly focused on the court's statements, i.e. the litigating parties' arguments are normally not considered, and the studies do not consider the context of the specific case. Rather the lexical items of the texts are in focus. This paper contributes to the existing literature by analyzing the litigating parties' arguments, in addition to those of the courts, and by analyzing the arguments in the context of the letter of the law, procedural law, company valuation models, financial theory and practice, the writers and their purposes, and the particular features of the case. The idea behind this paper is to employ the notion of hedging to guide the search for how uncertainties are rhetorically handled and constructed in a court case where the value of a financial instrument needs to be established.

\section{The rhetorical handling of uncertainty in the case}

After coding the documents (see Table 1) three categories of how uncertainty is rhetorically handled and constructed emerged (see Figure 1). The first category, "Clarification of the knowledge claim," consists of hedges qualifying the truth value of a proposition, i.e. epistemic modal expressions. The second category "References to the litigating parties," consists of expressions qualifying the truth value of a proposition by referral to either oneself or to the counterparty, subjectivizing the claim. The third category, "References to the knowledgeable" consists of referrals to conventional wisdom or statements made by ex- perts, enhancing the knowledgeable as a subject. In other words, one knowledge claim is supported by another (for instance a claim made by an expert), where the supporting claim almost assumes the character of a fact.

The first category, "Clarification of the knowledge claim," which consists of epistemic modal expressions, contains 22 hedges, of which 6 have been identified in the court decisions and 16 in the arguments made by the Tax Agency.

The second category, "References to the litigating parties," contains 20 references, 18 of which are related to claims made by the Tax Agency, 4 of them are references to the counterparty and 14 to the Tax Agency itself. A reference to the counterparty can reduce the degree of uncertainty by concluding that both sides agree, hence there is no reason to question the claim. Referencing oneself (in this case the Tax Agency) could function as a hedge subjectivizing the claim: "this is merely our view." Hence, it could also be read as "it doesn't have to be anyone else's view." The subject followed by a verb of cognition other than know, such as believe, marks the claim as subjective, which might invite the reader to agree or disagree from a dialogue point of view (Klimczak and Dynel 2018). Also, Salager-Meyer $(1994,154)$ includes expressions such as "I believe" in the taxonomy of hedges, since it "express the authors' personal doubt and direct involvement." Here the subject is expressed as a third person, i.e. "the Tax Agency believes," since the writer acts on behalf of the Tax Agency. However, the subject serves the same function in the third person as in the first.

The third category, "References to the knowledgeable," contains 31 references, 6 by the courts, 16 by the Tax Agency and 9 by the taxpayer. Of the court's references, five referred to independent valuations, experts, or reputed actors, and one to scientific basis and accepted practice. Of the references made by the Tax Agency, six referred to independent valuations, experts or reputed actors, and 10 to scientific basis and accepted practice. Of the taxpayer's references, seven concerned independent valuations, experts or reputed actors, and two scientific basis and accepted practice. From a linguistic point of view, however, referencing a third party does not constitute a hedge since it serves to reduce the degree of uncertainty, rather than to show open-mindedness about one's proposition. Rather, it works to place one's position as close to certainty as possible, but it operates on the same scale as the hedge, from uncertain to certain. Therefore, it shares some of the characteristics of a hedge. The reference serves to rhetorically handle uncertainty, and to protect the utterer. Of course, the reference could be viewed as a way of legitimizing the decision by referencing an authority (Van 


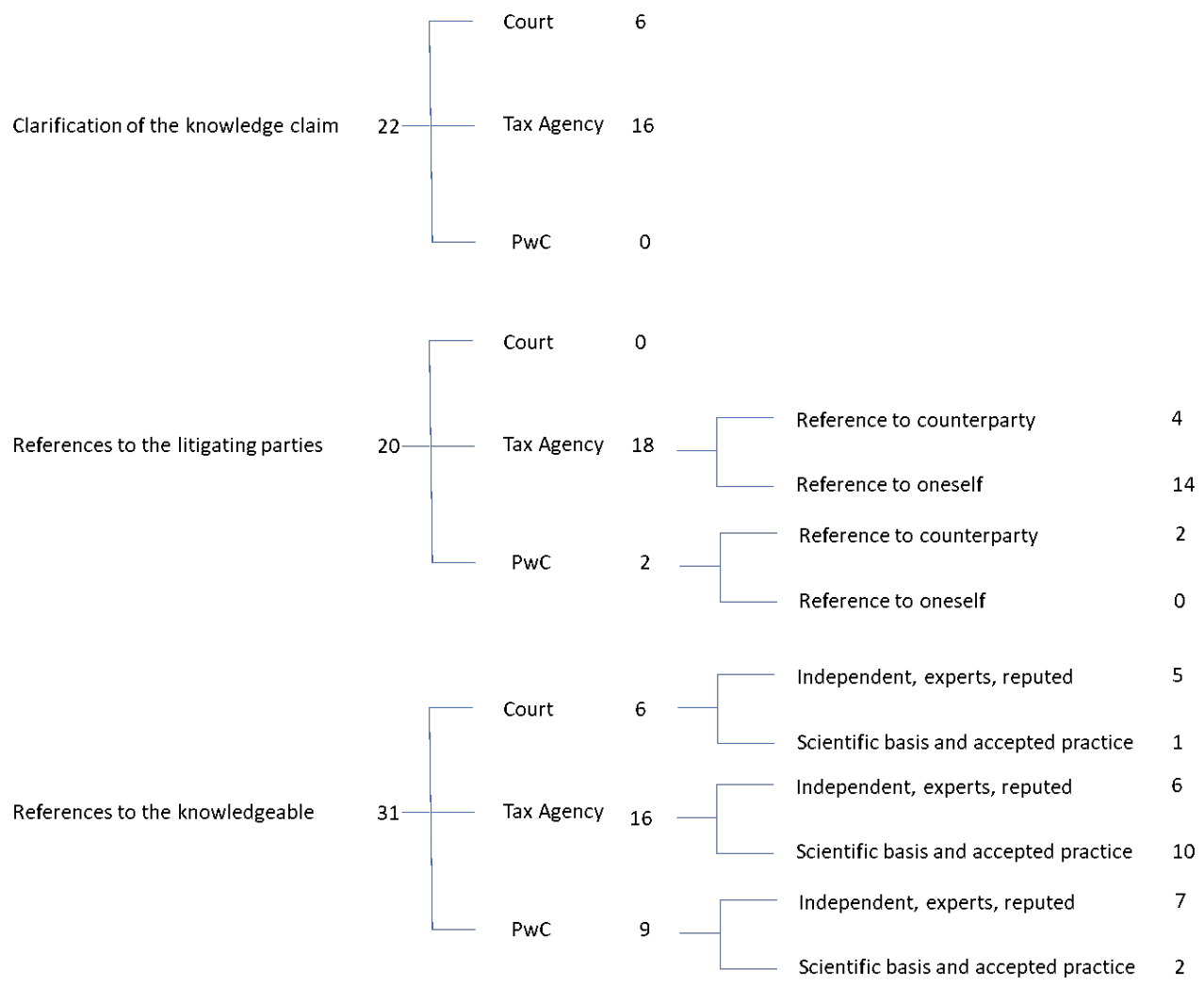

Figure 1: Categories of rhetorical handling and construction of uncertainty identified in the empirical material.

Leeuwen 2007). Almost like the quotation of a precedent, it does "the strategic linguistic work of protecting a decision” (Hinkle et al. 2012, 424). By quoting a precedent the legal reasoning is shielded. Referring to another subjectan expert or more abstractly the scientific community or the common-also functions to shield the argument, albeit in this case merely by a claim of another. Next, we will analyze and exemplify the three categories of rhetorical handling and construction of uncertainty.

\subsection{Clarification of the knowledge claim}

Epistemic model expressions are sparsely used. There seems to be less reason in these legal texts to soften the knowledge claims than in many other texts, such as academic texts (Corley and Wedeking 2014; Szczyrbak 2013). This is perhaps most apparent for the taxpayer, $\mathrm{PwC}$, that does not soften their claims at all. There is perhaps no reason to take a defensive stance, since the premise is that the taxpayer is correct until proven wrong. The burden of proof for additional taxable income rests with the Tax Agency (Lindkvist 2016). Therefore PwC presents its arguments as facts rather than as claims, and a fact is not hedged.
For the Tax Agency the sparse use of hedges, even though the claims actually are impregnated by uncertainty, can be traced to the requirement of the Tax Agency to be objective (The Constitution of Sweden: The Instrument of Government 1974:152) and, due to the burden of proof, to show probability. The courts, which seldom use epistemic modal expressions, need a rhetoric of certainty, since a dialogic language risks creating an impression that the rulings are uncertain, unclear, and contestable. Hence, there is a need to make the uncertain appear certain. This is rhetorically handled partly by refraining from the hedging of uncertain claims. As an example, it would not be wise for the Tax Agency to write that "the value could be SEK 35,000." Rather it is necessary to write "the value is SEK 35,000." The few epistemic modal expressions in the texts are rather used for sub-arguments. The expressions identified in the texts are mitigators such as "likely," "appears," "can," "indicates" (as in excerpt 1), "should," "some" (as in excerpt 2), "to a certain degree," "in principle" (as in excerpt 4), "reasonable to assume," "cannot be considered," "normally," and "under these circumstances." 
One example is presented in excerpt 1 , where the Tax Agency uses the word "indicates" to soften the claim that a high dividend implies a higher market value.

\section{Excerpt 1: Which indicates}

In view of the definition of market value in accordance with the Income Tax Act, Chapter 61, Section 2, Paragraph 2, the taxpayer would, in the Tax Agency's opinion, have had to pay a significantly higher price than SEK 10 for a share that gives such a high dividend, which indicates a market value that significantly exceeds SEK 10. (The Tax Agency's review decision, December 20, 2012, p. 9, my translation)

The argument in excerpt 1 is not a key claim, since it merely states that the broad definition of a market value in itself, before conducting the valuation of the company at hand, points to a value that materially exceeds the price paid for one share. It is rather a sub-argument pointing in a certain direction, and as such it is possible to hedge.

In the court decisions, six epistemic modal expressions have been identified. One of these hedges is exemplified in excerpt 2, where the Administrative Court, by the use of the word "some," states that the Tax Agency has received a certain amount of support from an expert opinion. The hedge in this case relates to the knowledge claim that there is support, although not very strong support, for the valuation presented by the Tax Agency, i.e. it clarifies the degree of support from the expert opinion, making the claim more precise and perhaps accurate.

\section{Excerpt 2: Some support}

The Tax Agency's valuation gains some support in a cited opinion from Oliver Wyman $\mathrm{AB}$ in which it is stated that the Tax Agency's valuation is in the lower part of possible valuations. However, the opinion states certain reservations for this position. (The Administrative Court in Stockholm, pp. 9-10, my translation)

Another kind of hedge is the following presented in excerpt 3. The Administrative Court of Appeal states that it cannot find that the Tax Agency has shown that the estimated market value compensates for the risk in return. This can be read as a hedge, since it softens the claim by the court. The court is, due to the hedge, not claiming that the Tax Agency is wrong; the market value calculated may very well compensate for the risk in return, as claimed. In the eyes of the court, though, the Tax Agency has not shown-"cannot [...] be considered to have shown"-that the claim is correct.

\section{Excerpt 3: Cannot be considered to have shown}

With regard to the investigation conducted by the company and the absence of an independent market valuation from the Tax
Agency, the Administrative Court of Appeal finds that all restrictions and obligations that also entail a risk in return on the investment should be taken into account when estimating the market value. The Tax Agency cannot, according to the Administrative Court of Appeal, be considered to have shown that the amount estimated by the agency compensates for the risk in the return. (The Administrative Court of Appeal in Stockholm, p. 8, my translation)

Even though the Tax Agency doesn't use hedges very frequently, these linguistic items are more common in the texts produced by the Tax Agency than in texts produced by the court or by the taxpayer. The single most common epistemic modal expression used by the Tax Agency is "in principle.”

\section{Excerpt 4: In principle}

The method has been chosen because the value of the company in this case in principle exclusively consist of the expected dividends. (The Tax Agency's review decision, December 20, 2012, p. 11, my translation)

The words "in principle" imply that the knowledge claim is toned down. An interpretation could be that the claim, in this case that the value exclusively consists of expected dividend, is very close to correct, although the utterer chooses to mitigate the claim on the margin, if there is something else that to some extent can affect the value. "In principle" in excerpt 4 tells the reader that the value does not exclusively consist of dividends, but almost.

Excerpts 1-4 above illustrate what epistemic modal expressions, as mitigators, do to knowledge claims in a legal argument. Even though the hedges can be read as clarifications of the knowledge claim, it is not clear to what extent the hedges actually function to make the knowledge claim more accurate, or if the hedges mainly function as a protection for the utterer motivated by a need to save face. However, it does something to the argument. Either it helps the reader to evaluate the degree of certainty in the truth claim, or it protects the utterer in the eyes of the reader from being regarded as naive or incompetent when claiming a precise value of a non-traded financial instrument.

\subsection{References to the litigating parties}

It is fairly common that the Tax Agency, when presenting a knowledge claim, makes reference to itself (14 times) as being the one making the claim. Four times such a reference is also made to the taxpayer. When referencing itself the Tax Agency subjectivizes the claim. A subjectivization can be read as "this is merely our opinion about the truth" 
(Hyland 1996b; Klimczak and Dynel 2018; Salager-Meyer 1994). In excerpt 5 , the claim that the market value is SEK 35,000 is the Tax Agency's estimation of it.

\section{Excerpt 5: In the Tax Agency’s estimation}

In the present case, the market value at the time of the acquisition, in the Tax Agency's estimation, amounted to SEK 35,000 per share, compared to the value stated by the company of SEK 10 per share. (The Tax Agency's review decision December 20, 2012, p. 16, my translation)

The Tax Agency refers to itself by formulations such as "the opinion of the Tax Agency," "the assessment by the Tax Agency,” "the Tax Agency's estimation.” Rhetorically, the claims are portrayed as being subjectivized, which in some contexts could be interpreted as hedges mitigating the claim. Read in the context of a litigation process handling financial economics (see Hyland 1996b, Mortensen and Mortensen 2017, and Resche 2015, on the importance of understanding hedges in the context in which they are applied), it seems more reasonable to understand these subjectivizations as a way for the Tax Agency to show respect to the legal system and the court. This could be read as a politeness strategy, as suggested by Myers (1989), but another perhaps more compelling interpretation, in line with genre theory where the genre refers to "large-scale typification of rhetorical action" acquiring meaning for a social context (Miller 1944, 163), would be to understand it as an institutionalized form of writing, including generic artefacts (Bhatia 2002; Czarniawska-Joerges and Joerges 1988; Miller 1984), emanating from the procedural form where the Tax Agency presents the case and its conclusions, yet acknowledging that the final decision (the final construction of the truth) is made by the court. Hence, it is not necessarily a strategic hedge in the moment of writing, which weakens or tones down the claim made by the Tax Agency, but rather an institutionalized politeness, emanating from a respect for the role ascribed to the Agency in the taxation process.

In some cases, the Tax Agency refers to the taxpayer, for instance in excerpt 6 :

\section{Excerpt 6: The Tax Agency referring to the taxpayer}

According to information from the company, the latest dividend amounted to a total of about SEK 180,000 for the 15 B shares. (The Tax Agency's review decision December 20, 2012, p. 3, my translation)

The references to the company by the Tax Agency, subjectivizing the taxpayer, such as "according to the company," implies the transfer of responsibility of a claim to the counterparty. More importantly, though, the reference creates facts. When there is an agreement between the litigating parties the reference to the counterparty makes it easier to establish a claim as fact. In that sense it is not a hedge, because the claim, provided that the counterparty is not misquoted, will not be contested. If everyone agrees upon a statement it can be regarded as facts by the court, not a claim. Hence, referring to the counterparty, more than anything else, constructs certainty.

In the case studied it is rare that the taxpayer refers to the Tax Agency, and when they do on two occasions, it is not about establishing facts or hedging uncertainty. Rather, as shown by excerpt 7, the rhetorical effect seemingly is to undermine the credibility of the Tax Agency.

Excerpt 7: The taxpayer referring to the Tax Agency undermining its credibility

However, the Tax Agency seems to believe that a valuation according to this definition can produce many different outcomes depending on whether it is an acquisition or a transfer, but also depending on which category of income [labor or capital] taxation will occur in. (PwC's submission to the Swedish Tax Agency, January 31, 2013, p. 3, my translation)

The word "seems" can in some contexts be understood as a hedge, in this case hedging the accuracy of the taxpayer stating what the Tax Agency has uttered. However, here the word "seems" is rather a booster, functioning to undermine the Tax Agency's credibility by emphasizing that its claim is unreasonable, illogical, incorrect, or downright ridiculous. PwC never refer to itself. By avoiding doing so, the company rather constructs its arguments as objective, generalizable, bordering on being facts.

\subsection{References to the knowledgeable}

The most common way to rhetorically handle uncertainty, protecting the utterer, is by referring to the knowledgeable. This means that the one making the argument, no matter whether it is one of the litigating parties or the court, handles the uncertainty of a claim by using another claim, either the claim of another identifiable physical person-the expert or expert knowledge-or the perceived claim of abstract persons-the shared knowledge of the scientific community or conventional knowledge. In both cases the supporting proposition needs no further evidence substantiating the accuracy of the proposition, at least not as long as it is uncontested by the litigating parties. As already mentioned, the handling of uncertainty by reference to the knowledgeable is very different from a hedge. Instead of opening up for alternative interpretations, as the hedge does, the reference to the knowledgeable serves to close 
this possibility, though still operating on the scale from uncertainty to certainty.

\subsubsection{Independent, experts, reputed}

An important feature of the argumentative texts studied is the substantiation of claims by claims made by others. These "others" are referred to in the texts as experts or reputed scholars that act independently of the two litigating parties, as well as of each other. By being referred to, and perhaps acknowledged by the court, as expert opinions, these claims are ascribed a high degree of facticity. The Tax Agency refer to claims by someone that is described as "independent," "expert," or "reputed" six times, the taxpayer seven times, and the courts make such references five times.

In excerpt 8 a reference by the Tax Agency to an "independent external valuation company" supports the claim that the applied valuation model is "accepted and applicable."

Excerpt 8: The Tax Agency referring to an independent external valuation company

The fact that the model is accepted and applicable in this case has also been confirmed by an independent external valuation company. (The Tax Agency's mandatory review decision, March 26, 2013, p. 5, my translation)

In excerpt 8 it is emphasized that the valuation company is independent of the litigating parties, and to stress the independence further-since the Tax Agency itself should be, if not independent, at least objective-it is also emphasized that the valuation company is an external company. The reference made in excerpt 8 is a reference to a company hired by the Tax Agency to comment upon the valuation model used by the Tax Agency, although not to make a so-called independent valuation. In other instances, the Tax Agency refers to the taxpayer's experts to the extent that they confirm the position of the Tax Agency.

The taxpayer who has hired two experts emphasizes this in four submissions to the Tax Agency and to the courts. In the submissions they present these external consultants as "highly reputable," "knowledgeable," and "independent of each other." The taxpayer also describes their reports as "external valuations" and "independent valuations." It is an important part of the taxpayer's argument that the experts confirm their position. In the appeal to the Administrative Court (excerpt 9) the taxpayer states that they have commissioned two of the "world's foremost valuers" who have conducted independent valuations of the PwC shares.

Excerpt 9: The taxpayer referring to experts and independence

PwC then commissioned two of the world's foremost valuers to conduct an independent market valuation of the shares in PWC. (PwC's appeal to the Administrative Court in Stockholm, March 25, 2013, p. 1, my translation)

In the claim to the Administrative Court of Appeal (excerpt 10), $\mathrm{PwC}$ refers to the two experts (portrayed as academics) as "exceptionally knowledgeable," having conducted independent valuations and independently of each other have reached the same conclusion, i.e. that the value of the shares is no higher than what the taxpayer claims.

Excerpt 10: The taxpayer referring to independence and reputable academics

Secondly, PwC has presented independent valuations from two very reputable and, in valuation, exceptionally knowledgeable academics who independently of each other concluded that the value on an open market is not higher than SEK 10. (PwC's plea to the Administrative Court of Appeal in Stockholm, February 28, 2014, p. 6, my translation)

Finally, the courts too support their conclusions by referring especially to the two experts hired by the taxpayer. And the courts actually put a lot of trust in these so-called independent valuations. In excerpt 11 the Administrative Court of Appeal concludes that the Tax Agency has not obtained any independent valuation. This is an important part of the court's argument for reaching its conclusion and arriving at its decision.

\footnotetext{
Excerpt 11: The court notes that the Tax Agency failed to obtain an independent valuation

The Administrative Court of Appeal further notes that the Tax Agency has not obtained an independent market valuation. (The Administrative Court of Appeal in Stockholm, p. 7, my translation)
}

In excerpt 12 the Administrative Court argues that the Tax Agency has not been able to convince the court that the critique put forward by the experts is wrong. Hence, the Tax Agency has not convinced the court that its valuation is the most correct one. Again, the court emphasizes that the experts have reached their concurrent conclusions independently of each other.

Excerpt 12: The court emphasizes independent valuation

The Tax Agency's valuation does not take into account these restrictions and obligations and the Tax Agency has not put forward any convincing arguments against the other criticisms that [Professor C and Professor S], independently of each other 
and essentially in agreement, put forward against the Agency's valuation. (The Administrative Court in Stockholm, p. 11, my translation)

It is clear from the case that the court put a lot of emphasis on the "independent experts" and that the Tax Agency has failed to obtain such a valuation (Hilling, Sandell, and Vilhelmsson 2018). Interestingly, by doing the latter the court questions either the Tax Agency's objectivity, ${ }^{8}$ (which actually is the role of the court in a contradictory process where the Tax Agency is one of two litigating parties, representing the public) and/or the competence of the Tax Agency to conduct a qualified valuation of the company share by itself. What is the logical reasoning behind emphasizing valuations by non-randomly selected "experts" to a higher degree than the valuation by the experts at the Tax Agency? Either the competence of the Tax Agency is questioned, or the court, due to the lack of understanding, needs something palpable to lean on. Otherwise the court could focus on discussing the arguments of the litigating parties, not the arguments of someone else.

The judges of the courts are not experts in financial economics on which a company valuation is based. Given the complexities of the financial models applied and the non-observable data input, the focus might be drawn to who is more trustworthy, telling the most believable story of data accuracy. A story that makes sense of facts through a narrative construct (Mattsson and Larsson 2014; Olchowy 2003) might be as important or even more important than the correctness of the actual data applied. Also in the court decisions in The Swedish Tax Agency v. PwCcase, in what way facts are told seems to take precedence over which the facts are (Hilling, Sandell, and Vilhelmsson 2018).

The requirement on the Tax Agency's story is then much higher, since it is up to the agency to show probability. When deciding upon trustworthiness, superficial arguments such as obtaining "independent valuations"rather than value-relevant arguments-seem to take precedence. The court distances itself from its own claim-its decision-by referring to the fact that someone else know better, and the court put its trust in that someone. The court's decision is then protected by the conclusions of those "independent experts." Since none of the litigating parties' questions that the witnesses are independent or

8 According to the Constitution of Sweden: The Instrument of Government (1974:152) [Regeringsformen], Chapter 1, Section 9, courts and authorities, such as the Tax Agency, that perform public administration duties must take into account that everyone is equal before the law and act with objectivity and impartiality. (Swed.) experts, their input gains the status of being close to fact, which at a first glance seems indisputable.

The idea of the experts being independent seems to be taken for granted. First, the experts are regarded as independent in general, which could be interpreted as independent of the two litigating parties. Second, the experts are regarded as independent of each other. These assumptions are very important for the supporting claim to have the close-to-a-fact status. Despite being unquestioned and presented as a fact, these assertions are not completely true, or actually not true at all.

As to the idea that the experts are independent of the litigating parties, the two expert testimonies obtained by the taxpayer who, unlike the Tax Agency, does not have to be objective-do not have to take into account circumstances that point in another direction than to the taxpayer's position. PwC have submitted two expert opinions, claiming that the experts and their valuations are independent. It might very well be-which the court has no knowledge about-that they have conducted their valuations without any interference from the party paying their fee, i.e. the taxpayer. No doubt, though, the taxpayer would not have handed in any expert opinion that was not in line with its own position. Hypothetically, the taxpayer might have consulted twenty experts, two of which came to this conclusion. Since it is not a random selection of valuation experts, and since the valuations presented to the court by the taxpayer will certainly support the taxpayer's position, it is actually not reasonable to address them as independent. Although, the idea of independency might be institutionalized and not questioned by the litigating parties, which could otherwise be expected in a contradictory process.

As to the second idea, that the two experts have reached their conclusions independently of each other, it might very well be the case that the two experts have not had any contact with each other. However, even if that is the case, both experts' reports depend on the taxpayer to be presented to the court, meaning that they have to be in line with the taxpayer's position. No matter whether the experts have performed their valuations independently of each other, they are dependent on the taxpayer, and being dependent on the taxpayer the experts cannot be said to be independent of each other, at least not their conclusions.

There seems to be a mix-up in the rhetoric between being independent and external. Since no one questions the notion of independence, the idea of independence and the claims made by the independent take the form of facts that are used to support a claim made by one of the litigating parties or by the courts. Especially for the courts the supporting claim serves to protect the utterer. Apparently, the 
discourse community-the Tax Agency, the courts, and perhaps lawyers participating in the legal valuation gamehas accepted the idea of so-called "independent valuations.”

\subsubsection{Science-based, accepted practice and conventional knowledge}

A position taken by any of the litigating parties, as well as by the court, is generally strengthened if it is grounded in science-based facts or at least what could be identified as accepted practice by professionals. Adding to this, claiming that a knowledge claim rather is conventional knowledge assumes that the knowledge claim is as close to being a fact as it can be. The implicit subject is the knowledgeable one, i.e. an imagined scientist, practitioner, or the public.

In the case 13 claims are supported by the claim that the position taken, by the litigating parties or by the court, is based on scientific knowledge or is an established practice. Referring to something being common knowledge or accepted practice gives authority by tradition or conformity (Van Leeuwen 2007). This is what we do in general, and what others do. And what we do is often perceived as the right thing to do. It is at least difficult to argue that it is wrong. The Tax Agency makes ten of those claims, the taxpayer two and the courts one.

In several submissions to the court the Tax Agency supports its arguments on this basis. Excerpt 13 is an example where the Tax Agency asserts that the valuation model (the NUTDEL model) corresponds to the "broad practice in the financial markets," i.e. is accepted practice, and corresponds with "established financial theory," i.e. is based on scientific knowledge.

Excerpt 13: Referral to practice and established theory

The Tax Agency's valuation of $\mathrm{PwC}$ using the NUTDEL model is done entirely according to broad practice in the financial markets and established financial theory. The method is also confirmed by [Professor S], among others. (Tax Agency's submission to the Administrative Court of Appeal in Stockholm, April 14, 2014, p. 6, my translation)

The taxpayer does not refer to science and practice to support their specific numbers or model, but rather for the necessity to bring in outside expertise. In excerpt 14 , PwC reminds the court that a valuation "must be done in a way that is consistent with science and practice." This can support the claim that the Tax Agency does not possess the competence to perform a valuation. Instead outside expertise needs to be brought in, as PwC does, on which they base their claim that the value $\mathrm{PwC}$ has used to price the instrument is reasonable, and more importantly, that the value calculated by the Tax Agency is not.

Excerpt 14: Consistent with science and practice

A company valuation must be done in a way that is consistent with science and practice. It is a complicated matter that requires a high level of education and long experience. (PwC's plea to the Administrative Court of Appeal in Stockholm, February 28, 2014, p. 6, my translation)

A last example is the rhetorical handling of uncertainty by reference to conventional knowledge. When the Tax Agency writes that "it is generally considered that net asset valuation is well suited for non-operating companies" (see excerpt 15) they use "generally considered" as a synonymous for conventional knowledge. The claim that it is conventional knowledge then functions as support for the claim that "net asset valuation is well suited for nonoperating companies." Conventional knowledge can be regarded as encapsulating both scientific knowledge and best practice.

\section{Excerpt 15: It is generally considered}

Thus, it is generally considered that net asset valuation is well suited for non-operating companies, while yield valuation may be better suited for operating companies in the knowledge sector, of the kind that PwC belongs to. (The Tax Agency's review decision December 20, 2012, p. 12, my translation)

\section{Discussion and conclusion}

This paper is an attempt to understand how uncertainty is rhetorically handled and constructed within tax litigation, concerning the valuation of non-traded company shares. Due to the characteristics of a company valuation, the litigating parties need to convince the court not only of the possibility to look into the future, but also of the possibility to practice prophecy. Those prerequisites will of necessity increase the degree of uncertainty in the decisionmaking process. In this paper, the notion of hedging, along with the linguistic structures behind this notion, has been used, not in order to develop any typology of hedging, nor to take part in the debate of which linguistic items constitute hedges, but as a means to identify and categorize writings that perform the function of handling and constructing uncertainty.

In general, in order to understand how justice works, and how justice is practiced, it is important to understand how claims and perceived facts are presented to the court and how a convincing story is formulated by the litigat- 
ing parties as well as by the court (Olchowy 2003). For instance, it is important to understand what it takes to convince the court to such an extent (for the Tax Agency to make its claim probable, for the taxpayer to show that the Tax Agency has failed in making its claim probable) that the court feels confident that it can write a convincing ruling, in either direction. Although it is difficult to quantify the importance of language and storytelling, studies like this can shed light on how narratives function in litigation (Hinkle et al. 2012; Newberg 2002). The stories told to the court, and the story told by the court, might contain attributes that we need to understand to decide if justice has been served. Sometimes it might not be the facts we need to evaluate, but rather the language, legitimizing statements as facts, even though they are nothing more than more or less convincing claims. In other words, we need to analyze the language use in order to analyze not only the individual ruling, but also the functioning of the legal system as a whole, or at least with regard to a particular question, in this case the valuation of non-traded company shares.

The study of language use is necessary in order to understand which knowledge claims are made, the depth of the knowledge claims presented-i.e. what is the substance they are based on-and which knowledge claims are taken for granted as institutionalized facts. This is important in order to understand how cases are argued, but also how the courts reach their conclusions. All individuals-officers of the court being no exception-are limited by the current discourse, concerning line of thought, making an argument and reaching conclusions (Svensson 2019). Language and pre-knowledge (Bazerman 1985; Higdon 2009; Sherwin 1993; Vass 2004) limit the ability to understand a complex body of material and reach a conclusion. Hence, knowledge claims might pass without reflection as factual statements because they are not contested by the discourse community. Claims that should have been thoroughly scrutinized might be accepted as facts because it is practical. In other words, the discourse makes society work.

In the case of The Swedish Tax Agency v. PwC (2013, 2014) the hedges are few, even though the degree of uncertainty is high. This can be understood from the nature of litigation. Rhetorically there is not much room for being uncertain (Corley and Wedeking 2014; Szczyrbak 2013). Facticity is the rhetorical norm of this legal discourse. The "logico-scientific story form" tends, as Sherwin $(1993,689)$ remarks, to correspond to the burden of proof. Hence, one generally does not soften the knowledge claims in order to be more accurate. The demands on the level of evidence and objectivity mean that neither the Tax Agency nor the court can rhetorically soften their claims, because a weak claim is not perceived as sufficiently objective, certain or credible. The taxpayer, on the other hand, has no reason to be rhetorically uncertain, especially not in the case studied where the taxpayer is an expert in company valuation as well as taxation. The court also needs to appear certain in the presentation of the ruling, even if it were warranted to use hedges in order to represent the uncertainties as they are. Acknowledged uncertainties invite the losing party to contest the ruling; the legitimacy of the legal system might be questioned and the ruling might lose its ability to guide other courts.

Whereas the epistemic modal expressions categorized as "clarification of the knowledge claim" (see excerpts 1-4 above) are fairly uncommon, the other two categories identified present interesting rhetorical functions that need to be analyzed in their context. The first one is "references to the litigating parties," where the Tax Agency subjectivizes itself (see excerpts 5-7 above), and the second one is the "references to the knowledgeable," supporting a claim by another claim, using the knowledgeable as a subject, i.e. the abstract idea of an expert, where the supporting claim is ascribed the discursive status of a fact (excerpts 8-15 above).

The Tax Agency subjectivizing itself, i.e. referencing itself, can be exemplified with the following sentence: "The Tax Agency therefore finds that it is shown that the valuation used by PwC is not applicable [...]." An alternative, more straightforward, way of presenting this claim would be: “The valuation used by $\mathrm{PwC}$ is not applicable." In some contexts, subjectivization has been regarded as a hedge (Hyland 1996b; Klimczak and Dynel 2018; Salager-Meyer 1994), as the formulation draws the readers' attention to the fact that it is merely the opinion or conclusion of the utterer. The subjectivization of the Tax Agency in the PwC case can be interpreted in at least three ways. First, as "it is merely our opinion," i.e. the Tax Agency then indirectly would say that this is not the only possible opinion. Second, drawing on the first, it would be possible to read into the subjectivization that "valuation is by definition subjective," and the subjectivization makes the claim more accurate regarding the truth value of the claim. Third, the subjectivization could be interpreted, in line with Myers (1989), as a politeness strategy. I would argue that the reference to itself should not be interpreted as how the Tax Agency handles uncertainty. The reference to itself does not imply that there is any lack of confidence. Rather, the Tax Agency's reference to itself is a form of institutionalized respect of the litigation process, which by all means is a form of politeness strategy, in line with Myers (1989). It is an acknowledgment that it is the Tax Agency that ar- 
gues the case, but it is the court that makes the decision. However, it is most likely not a strategic politeness initiative by the writer in the moment. An alternative and perhaps more plausible explanation would be that the reference to itself is an institutionalized artefact (Bhatia 2002; Czarniawska-Joerges and Joerges 1988), which at one point in time might very well have sprung from a politeness act of communication. If that is indeed the case only further historical research may convey.

Even more interesting, in respect of uncertainty, are the references to independent experts and conventional knowledge that not only the Tax Agency and the taxpayer refer to, but also the courts adhere to. The idea is that since an expert, receiving legitimacy by the authorization as such (Van Leeuwen 2007), or sometimes the general business practice, supports a claim, the claim is understood to be more trustworthy. A claim by one of the litigating parties is then protected by another claim. When the so-called experts confirm the claim, the claim gets closer to becoming a fact, i.e. when the discourse community accepts a claim, it receives the status of fact (Crompton 1997; Hyland 1994, 1996b; Lewin 2005). Two experts, hired by one of the litigating parties, do not represent the discourse community as a whole, although rhetorically they seem to be accepted as representative by the court. As perhaps the judges' pre-existing knowledge, or embedded knowledge structures, are limited, it is reasonable to believe that the cognitive frames that would normally be used to make sense of the case (Berger 2008; Sherwin 1993) might be, to a larger extent, replaced by the pre-existing knowledge of others, i.e. the experts. When one doesn't know, one searches for something to hold on to, in this case something that can make one's assessment legitimate in the eyes of the discourse community.

When knowledge claims are supported rhetorically by claims of others, which seem to be accepted without scrutiny, the courts, as well as the Tax Agency, also participate in the reproduction of stereotypes as well as constructed and institutionalized truths and definitions, for example of "objectivity," "probability," "independent," and "expert opinion." Texts are not only a consequence of the context within they are written, but also take part in the reproduction, reshaping, and redefinition of the same context. It is also problematic, as has been shown (see excerpts 8-12 above), to refer to experts (if we accept this term) as "independent" or "independent of each other," which they are not, since they are both dependent on one of the litigating parties. If they had not reached the same conclusion as the party presenting their opinion, their conclusion would not have been presented to the court at all. The claim that they are independent rhetorically builds in more trust in their statements. The institutionalization of independence as fact is problematic from an intellectual point of view, but might be a practical way to make the impossible possible, i.e. to objectively calculate the value of a non-traded financial instrument.

Knowledge claims-made by the court or by the litigating parties-are uncertain and as such protected by other knowledge claims-those of the expert-with the aid of which one can distance oneself from, or reduce responsibility for, one's assessment (or lack thereof). These supporting claims functions to save face, convincing the reader and making the protected argument appear correct. By referring to someone else's argument one protects oneself. Such claims by others can be accepted as strong evidence. These supporting claims may be established truths in the discourse community and are as such not contested. They are rather taken for granted and do not need to be hedged, perhaps because they are perceived as factual.

The courts' decisions are not based on any value calculation performed by the courts. More striking perhaps is that the decisions are not based (or at least only to a small degree) on the valuations presented by the litigating parties either, where the court would scrutinize the models applied and the data input in order to reach a conclusion regarding who comes closer to the truth. It is rather a decision as to which one of the litigating parties is most believable, or presents the most compelling story, where of course much higher demands have to be placed on the Tax Agency. In that sense the decision is not necessarily about the facts of the case, which are difficult to grasp. Since the taxpayer in this case has the ability by itself to present a credible story, has the ability and means to hire "reputable" consultants, it gives them a rhetorical advantage, i.e. they are very well equipped, perhaps more so than the Tax Agency, to present a convincing argument. Such an advantage would not be feasible for another taxpayer, lacking the competence and means, to tell a compelling story. In that sense the outcome of a litigation is relative. In line with the conclusion of Hilling, Sandell, and Vilhelmsson (2018), given the same circumstances, the Tax Agency arguing a case against a "weaker" taxpayer may very well be able to convince the court. In a case such as this, where the uncertainty of a valuation is immense, it is not necessarily facts that are being tried by the court, but the stories told about facts.

This paper has emphasized, as suggested by Hyland (1996a, 1996b), Mortensen and Mortensen (2017), and Resche (2015), a contextual understanding in order to contribute to the knowledge of how uncertainty is constructed and handled by litigating parties and the court in a situation where a "correct" value must be established based on 
future events. It has also shed light upon what pre-existing knowledge is in play, and how the lack of such knowledge might be replaced, by knowledge of others receiving legitimacy from the court as perceived spokespersons for the discourse community.

\section{References}

Almgren, Karin and Börje Leidhammar. 2016. Skatteprocessen [The tax process]. Stockholm: Wolters Kluwer.

Bazelon, David L. 1981. "Science and Uncertainty: A Jurist's View." Harvard Environmental Law Review 5: 209-215.

Bazerman, Charles. 1985. "Physicists reading physics: Schemaladen purposes and purpose-laden schema." Written communication 2 (1): 3-23.

Berger, Linda L. 2008. “How embedded knowledge structures affect judicial decision making: A rhetorical analysis of metaphor, narrative, and imagination in child custody disputes." Southern California Interdisciplinary Law Journal 18: 259-308.

Bhatia, Vijay. (2002). "Applied genre analysis: A multi-perspective model." Ibérica: Revista de la Asociación Europea de Lenguas para fines específicos (AELFE) 4: 3-19.

Charmaz, Kathy. 2006. Constructing Grounded Theory: A Practical Guide Through Qualitative Analysis. London: Sage.

Cheng, Winnie and Le Cheng. 2014. "Epistemic modality in court judgments: A corpus-driven comparison of civil cases in Hong Kong and Scotland." English for Specific Purposes 33: 15-26.

Clemen, Gudrun. 1997. "The concept of hedging: Origins, approaches and definitions." In Hedging and discourse: Approaches to the analysis of a pragmatic phenomenon in academic texts, edited by Raija Markkanen and Hartmut Schröder, 235-248. Berlin: Walter de Gruyter.

Corley, Pamela C. and Justin Wedeking. 2014. "The (dis) advantage of certainty: The importance of certainty in language." Law \& Society Review 48 (1): 35-62.

Crompton, Peter. 1997. "Hedging in academic writing: Some theoretical problems.” English for Specific Purposes 16 (4): 271-287.

Czarniawska-Joerges, Barbara \& Bernward Joerges. 1988. "How to control things with words: Organizational talk and control." Management Communication Quarterly 2 (2): 170-193.

Diesen, Christian. 2003. Bevis 7 Bevisprövning i förvaltningsmål [Evidence 7 Evidence testing in litigation]. Stockholm: Norstedts juridik.

Edin, Per-Olof and Sven-Olof Lodin. 2008. "En analys av en felaktig analys av 3:12-reglerna." [An analysis of an incorrect analysis of the 3:12 rules]. Ekonomisk Debatt 36: 55-66.

Ekström, Simon. 2003. "Att tala sanning." [To speak the truth]. Tidsskrift for kulturforskning 2 (3): 5-21.

Enough, Birte and Thomas Mussweiler. 2001. "Sentencing under uncertainty: Anchoring effects in the courtroom 1." Journal of applied social psychology 31 (7): 1535-1551.

Evans, Lisa. 2004. "Language, translation and the problem of international accounting communication." Accounting, Auditing \& Accountability Journal 17 (2): 210-248.

Gold, Andrew S. 2006. "A Decision Theory Approach to the Business Judgment Rule: Reflections on Disney, Good Faith, and Judicial Uncertainty." Maryland Law Review 66: 398-474.
Hamer, David. 1994. "The civil standard of proof uncertainty: Probability, belief and justice." Sydney Law Review 16: 506-536.

Higdon, Michael J. 2009. "Something Judicious This Way Comes... The Use of Foreshadowing as a Persuasive Device in Judicial Narrative." University of Richmond Law Review 44: 1213-1260.

Hilling, Axel, Niklas Sandell and Anders Vilhelmsson. 2017. "Tax Planning in Partner-owned Close Corporations." Nordic Tax Journal 1 (1): 108-120.

Hilling, Axel, Niklas Sandell and Anders Vilhelmsson. 2018. "Lagen är lika för alla, men är alla verkligen lika inför lagen? En studie av Skatteverkets processföring i PwC-målet." [The law is equal for everyone, but is everyone really equal before the law? A study of the Swedish Tax Agency's litigation in the PwC case] Förvaltningsrättslig tidskrift 2: 269-286.

Hilling, Axel, Niklas Sandell and Anders Wilhelmsson. 2019. "The Pricing of Financial Instruments in Tax Disputes." Derivatives \& Financial Instruments 21 (2).

Hinkle, Rachael K., Andrew D. Martin, Jonathan D. Shaub and Emerson H. Tiller. 2012. "A positive theory and empirical analysis of strategic word choice in district court opinions." Journal of Legal Analysis 4 (2): 407-444.

Hyland, Ken. 1994. "Hedging in academic writing and EAF textbooks." English for Specific Purposes 13 (3): 239-256.

Hyland, Ken. 1996a. "Talking to the academy: Forms of hedging in science research articles." Written Communication 13 (2): 251-281.

Hyland, Ken. 1996b. "Writing Without Conviction? Hedging in Science Research Articles.” Applied Linguistics 17 (4): 433-454.

Hyland, Ken. 1998. "Exploring corporate rhetoric: Metadiscourse in the CEO's letter." The Journal of Business Communication 35 (2): 224-244.

Jalilifar, Ali R. and Maryam Alavi. 2012. "Power and politics of language use: A survey of hedging devices in political interviews." Journal of Teaching Language Skills 30 (3): 43-66.

Klimczak, Karol M. and Marta Dynel. 2018. "Evaluation markers and mitigators in analyst reports in light of market response to stock recommendations." International Journal of Business Communication, 55 (3): 310-337.

Klimczak, Karol M., Marta Dynel and Anna Pikos. 2016. "Goodwill impairment test disclosures under uncertainty." Journal of Accounting and Management Information Systems 15 (4): 639-660.

Lakoff, George. 1973. "Hedges: A study in meaning criteria and the logic of fuzzy concepts." Journal of philosophical logic 2 (4): 458508.

Lavin, Rune. 2020. Förvaltningsprocessrätt [The procedure of litigation]. Stockholm: Norstedts Juridik AB.

Lewin, Beverly A. 2005. "Hedging: an exploratory study of authors' and readers' identification of 'toning down' in scientific texts." Journal of English for Academic Purposes, 4 (2): 163-178.

Lindkvist, Gustav. 2016. Bevisfrågor i skatteprocessen: En översikt [Evidence issues in the tax process: an overview]. Stockholm: Wolters Kluwer.

Longstaff, Francis A. (2018). "Valuing Thinly Traded Assets." Management Science. 64 (8): 3868-3878.

Lyons, John. 1977. Semantics: Volume 2. Cambridge: Cambridge University Press.

Mattsson, Johan and Stefan Larsson. 2014. “Juridikens dolda tankestrukturer. Observationer av metaforbruk i den svenska civilrätten.” Tidsskrift for Rettsvitenskap 127 (05): 512-534.

McLaren-Hankin, Yvonne. 2008. "We expect to report on significant progress in our product pipeline in the coming year': Hedging 
forward-looking statements in corporate press releases." Discourse Studies 10 (5): 635-654.

Miller, Carolyn R. 1984. "Genre as social action.” Quarterly journal of speech, 70 (2): 151-167.

Mortensen, Sune S. and Janus Mortensen. 2017. "Epistemic stance in courtroom interaction." In Pragmatics and Law, edited by Francesca Poggi and Alessandro Capone, 401-437. Cham: Springer International Publishing.

Myers, Greg. 1989. "The pragmatics of politeness in scientific articles." Applied linguistics 10 (1): 1-35.

Newberg, Joshua A. 2002. "The narrative construction of antitrust." Southern California Interdisciplinary Law Journal 12: 181-216.

Olchowy, James R. 2003. "Battling for the Judge's or Jury's Imagination: Evidence, Storytelling, and Effective Trial Advocacy." Windsor Review of Legal and Social Issues 16 (1): 1-22.

Prasad, Pushkala. 2005. Crafting qualitative research: Working in the post-positivist traditions. Armonk, N.Y.: M.E. Sharp.

Resche, Catherine. 2015. "Hedging in the discourse of central banks." Studies in Communication Sciences 15 (1): 83-92.

Robertson, Bernard and G. Anthony Vignaux. 1993. "Probability-the logic of the law." Oxford Journal of Legal Studies 13 (4): 457-478.

Salager-Meyer, Françoise. 1994. "Hedges and textual communicative function in medical English written discourse." English for Specific Purposes 13 (2): 149-170.

Sandell, Niklas and Peter Svensson. 2016. "The language of failure: The use of accounts in financial reports." International Journal of Business Communication 53 (1): 5-26.

Sandell, Niklas and Peter Svensson. 2017. "Writing write-downs: The rhetoric of goodwill impairment." Qualitative Research in Accounting \& Management 14 (1): 81-102.

Sherwin, Richard K. 1993. "The narrative construction of legal reality.” Vermont Law Review 18: 681-719.
Svensson, Peter. 2019. Diskursanalys [Discourse analysis]. Lund: Studentlitteratur.

Szczyrbak, Magdalena. 2013. " "I think my own view is that...” On the Linguistic Construction of Evidence in Courtroom Discourse." Topics in Linguistics 12: 65-74.

Tai, Stephanie. 2008. "Uncertainty about uncertainty: The impact of judicial decisions on assessing scientific uncertainty." University of Pennsylvania Journal of Constitutional Law 11 (3): 671-728.

Taweel, Abeer Q., Emad M. Saidat, Hussein A. Rafayah and Ahmad M. Saidat. 2011. "Hedging in Political Discourse." Linguistics Journal 5 (1): 169-196.

Toska, Bledar. 2012. "Epistemic Hedges and Boosters as Stance Markers in Legal Argumentative Discourse." Topics in Linguistics 10: 57-62.

Van Leeuwen, Theo. 2007. "Legitimation in discourse and communication." Discourse \& Communication 1 (1): 91-112.

Vass, Holly. 2004. "Socio-cognitive aspects of hedging in two legal discourse genres." Ibérica: Revista de la Asociación Europea de Lenguas para Fines Específicos (AELFE) 7 : 125-141.

Vass, Holly. 2017. "Lexical verb hedging in legal discourse: The case of law journal articles and Supreme Court majority and dissenting opinions." English for Specific Purposes 48: 17-31.

Vold, Eva T. 2006. "Epistemic modality markers in research articles: A cross-linguistic and cross-disciplinary study." International Journal of Applied Linguistics 16 (1): 61-87.

Wang, Huili, Lixin Li and Jingxiang Cao. 2012. "Lexical features in corporate annual reports: A corpus-based study." European Journal of Business and Social Sciences 1 (9): 55-71. 